\title{
Romantikken og nutiden
}

Om "Kaos og Kosmos", red. af Hans Boll-Johansen og

Flemming Lundgreen-Nielsen. Museum Tusculanums

Forlag. Kфbenhavns Universitet 1989

af forskningsbibliotekar, mag.art. Johanne Slots

I løbet af de godt ti år, det har eksisteret, har forlaget Museum Tusculanum gennem en række væsentlige udgivelser markeret sig som en vigtig platform for dansk humanistisk forskning. Det har skabt nyt og større rum for videnskabelige arbejder inden for et vidtspændende felt, til glæde for såvel fagfolk og specialister som for et større publikum af "almindelige" interesserede læsere. Bøgerne kommer i et pænt, undertiden ligefrem smukt udstyr - som i det foreliggende tilfælde, hvor bogens billedredaktion (Marianne Marcussen og Hannemarie Ragn Jensen) har udvalgt karakteristiske værker fra billedkunsten og anbragt dem som et inciterende akkompagnement til bogens indhold.

Romantikken, som bevægelse, filosofi, litterær og kunstnerisk retning, er et stort og udfordrende emne, der kalder på fornyet undersøgelse og behandling fra forskerside. I Kaos og Kosmos. Studier i europaisk Romantik, udsendt af Museum Tusculanum i slutningen af 1989, er emnet taget op og udforsket fra mange synsvinkler. Bogen er en udløber af et tværfagligt seminar på Københavns Universitet i 1982-83, og dens udvalgte afhandlinger om romantikken er for størstedelen skrevet i 1984 (nogle dog med senere tilføjelser). Som i andre lignende tilfælde er udgivelsen kommet i stand ved hjælp af fondsmidler. At sikre sig sådanne fra forskellig side er en langvarig proces - derfor det sene publikationsår i forhold til affattelsestidspunktet. Denne "forsinkelse" har dog ikke mindsket bogens aktualitet.

Kaos og Kosmos består af ti artikler, en indledning ved Hans BollJohansen, samt til slut et kapitel (uden forfatternavn) om temaer og teknikker i romantikkens malerkunst. Dette sidste falder underligt uden for sammenhængen ved ikke at følge umiddelbart efter bogens to større artikler om kunst, skrevet af hhv. Hannemarie Ragn Jensen og Marianne Marcussen, og det i øvrigt forbliver uoplyst, af hvem disse afsluttende sider er forfattet. 
Mellem dem og Marcussens artikel er Boll-Johansens artikel om Romantik og nationalisme anbragt. Eftersom der er tale om selvstændige artikler med rod i forelæsningerne ved det førnævnte seminar, har man ikke søgt at forbinde artiklerne eller trække linier fra afsnit til afsnit, men det forekommer indholdsmæssigt mere konsekvent, om de tre artikler om malerkunsten var blevet stillet i en ubrudt rækkefølge, efterfulgt - som bogens sidste bidrag - af Hans Boll-Johansens artikel om romantikkens politiske ideer.

Artikelsamlingen begynder idémæssigt et andet sted. Efter Boll-Johansens givende indledning om det problematiske ved en definition af begrebet "romantik" står som bogens første afsnit Jørgen I. Jensens artikel Den fjerne Kirke, en unders $\emptyset$ gelse af forholdet mellem romantik og kristendom. Heri tages de romantiske forestillinger om anelsens betydning i tilværelsestolkningen op til belysning af romantikkens kristendomsopfattelse. Der sker i den romantiske periode en frigørelse fra dogmatikken og en søgen tilbage til ældre kristne former - til de første århundreders gammel-kristne tradition eller den fjerne, oprindelige kirke, uden om den aktuelle (19. århundredes) kirke som institution. I drømmen eller anelsen om den gamle, fjerne kirke (jf. s. 42-48 om Sibberns Gabrielis' Breve) bliver der rum for det personlige religiøse livs udfoldelse og erfaring og for en kristendom, der uden dogmatisk binding kan virke i kunstens univers. Som de bibelske billeder hos Oehlenschläger uafhængigt af den kirkelige dogmatik og eksegese bruges i et digterisk univers, således virker nu den kristne traditions frigjorte tankeformer "i de nye kulturelle sammenhænge, først og fremmest i de nye kunstinstitutioner". I litterære tekster kan de gamle kristne forestillingers fortsatte eksistens spores som en skjult struktur eller "et kun halvvejs synligt allusionsrum" (s. 34. - Der peges her på den litteraturkritik, der udøves af forskere som M.H. Abrams, Northrop Frye og herhjemme Aage Henriksen).

Den fængslende artikel begyndte med nogle sætninger, der aktualiserer forholdet romantik-kristendom: "Tænker man på, at nutiden er efterkommer af romantikken, må man ret hurtigt se den uventede mulighed i øjnene, at den romantiske - den anelsesfulde, glimtvise, udogmatiske og yderst labile kristendom er den mest udbredte religion i nutidens Danmark."

De romantiske tankeformers tilstedeværelse i vor egen tid viser én side af sammenhængen mellem romantikken og nutiden. En anden side kommer til syne, hvor romantiske anskuelser har foregrebet moderne fænomener. Eller sagt med andre ord - nutiden kan, med sin romantiske arv i behold, på visse områder fortsætte og bringe det til udfoldelse, som endnu kun lå i kim i romantikken. I Flemming Lundgreen-Nielsens artikel Sjalens natside. Det ubevidste $i$ dansk romantik træder forbindelsen mellem romantikernes skildringer af menneskesindet og moderne psykologi tydeligt frem. Længe før det 


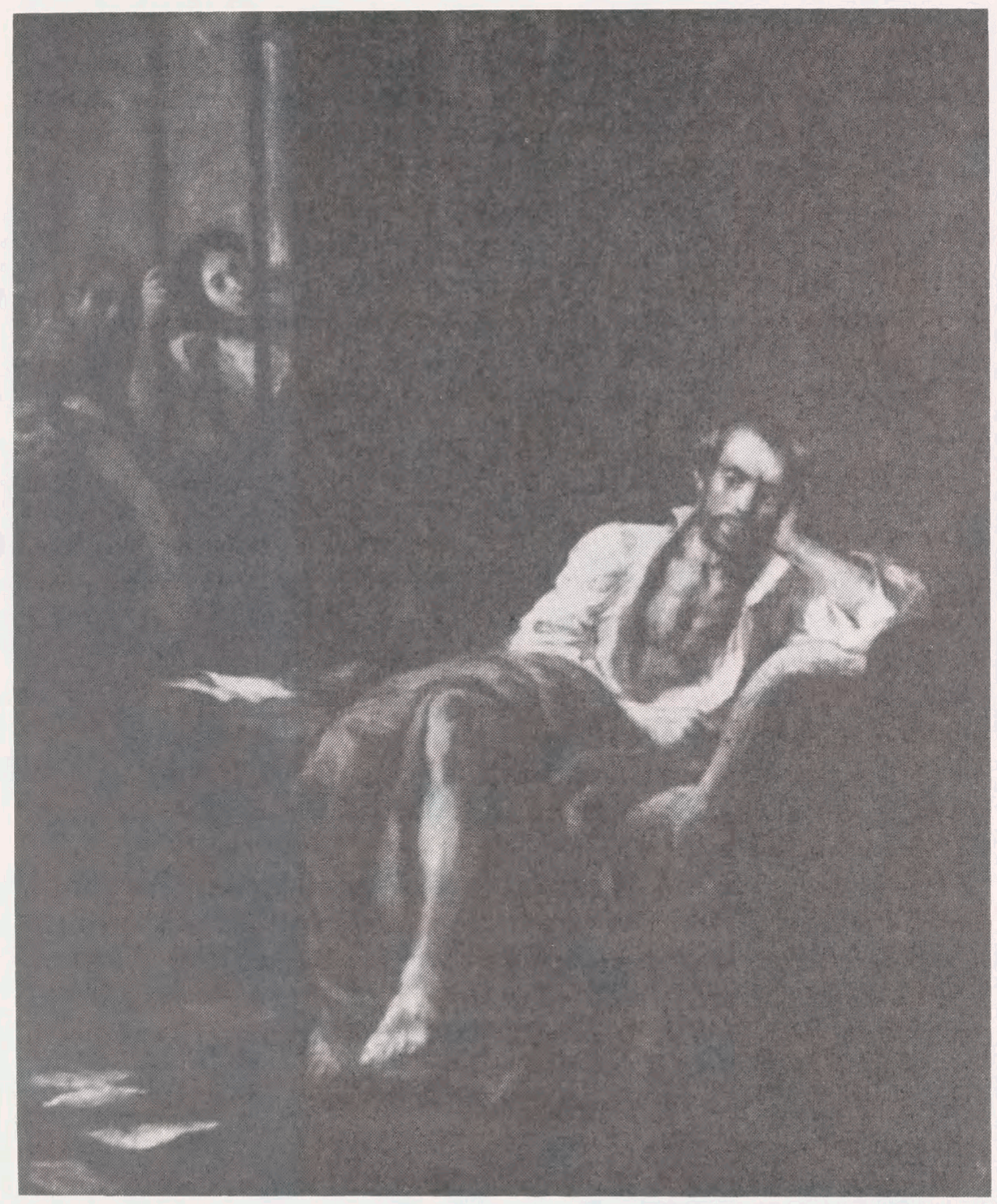

Eugène Delacroix, Tasso i galehuset, 1839. - Fra Kaos og Kosmos.

blev psykologisk videnskab og Freud fremlagde sine teorier om det ubevidste, interesserede de romantiske digtere sig for udforskningen af den individuelle personlighed; de begav sig så at sige ned i "bevidsthedens underverden" og konfronterede sig "med de styrende magter der" (s. 82). De fascineredes af sjælens dunkle rørelser og sindets afgrunde - sjælesygen, nervefeberen, vanviddet og dæmonien er gentagne motiver i deres værker - og de 
når i deres digteriske sprog langt $\mathrm{i}$ beskrivelsen af indre, ubevidste tilstande. Vi ser det hos blandt andre Staffeldt, Andersen, Paludan-Müller og, ikke mindst, hos den tidlige Ingemann. Lundgreen-Nielsens kyndige og spændende undersøgelse er rig på træffende teksteksempler.

Som filosofisk begreb er den grænseoverskridende og mangetydige romantik svær at få hold på. Arne Grøn påpeger i sin artikel Spittelse og forsoning. Filosofisk romantik og tysk idealisme, at romantikken kun optræder "som en marginal størrelse i filosofihistorien" (s. 55), medens romantikkens digtere til gengæld på hver sin måde optræder som filosoffer. Ud fra filosoffer som Schelling, Fichte og Hegel og under indkredsningen af forholdet eller forskellen mellem romantikken og tysk idealisme behandler Grøn et stort filosofisk problemkompleks, hvori begrebsforhold som splittelse og forsoning, fornuft og frihed, ideal og virkelighed indgår som de vigtige bestanddele de er i tidens historie- og kunstsyn. Et væsentligt element i sammenhængen er også fremmedgørelsens problem, der opstår af den individuelle og historiske erfaring af virkelighedens brudte helhed. Ligesom historien egentlig er frihedens historie - eller "der er kun en historie, hvis friheden er noget, der skal virkeliggøres" (s. 64), sådan er forsoningen, eller (gen)oprettelsen af virkelighedens sammenhængende helhed, målet. Hos Hegel igennem splittelsen (hvor forsoningen bliver til i den historiske proces), i den filosofiske romantik ved en umiddelbar genoprettelse af den oprindelige enhed (sker f.eks. i den æstetiske anskuelse).

At romantik og realisme ikke er kunstnerisk uforenelige størrelser kendes bl.a. fra den retning i 1820-30rnes danske digtning, som kaldes "poetisk realisme". Hans Peter Lund og Jørgen Erik Nielsen behandler romantik-realisme forholdet $\mathrm{i}$ fransk og engelsk litteratur med artikler om hhv. Balzac (og andre forfattere) og Byron (hans versfortælling "Mazeppa"). Hvor Lund vil undersøge, på hvilken måde romantikerne er realistiske, og her gransker digternes opfattelse af realismebegrebet, ikke alene som det kan aflæses i deres fiktionsværker, men også som det kommer til udtryk i deres æstetiske refleksioner, forholder Nielsen sig til en enkelt tekst, som fortolkes under sammenligning med et andet digt i samme forfatterskab ("The Giaour"). Begge bidrag klargør nogle afgørende træk ved romantisk digtning. Realismen kan ses som en prætention i romantikken, og de to retninger kan snart arbejde sammen, snart kontrastere i det romantiske digterværk. Balzacs "tematisk set romantiske romaner søger hele tiden en realistisk kontekst" (Lund, s. 126) - i Byrons "Mazeppa" er det kontrasten mellem den romantiske fortælling og dens realistiske ramme, der giver digtet dets særpræg (og romantiske ironi).

Jan Maegaard behandler samme begrebspar musikhistorisk i artiklen Romantik og realisme i musik. Medens "romantisk musik" er et gængs, noget 


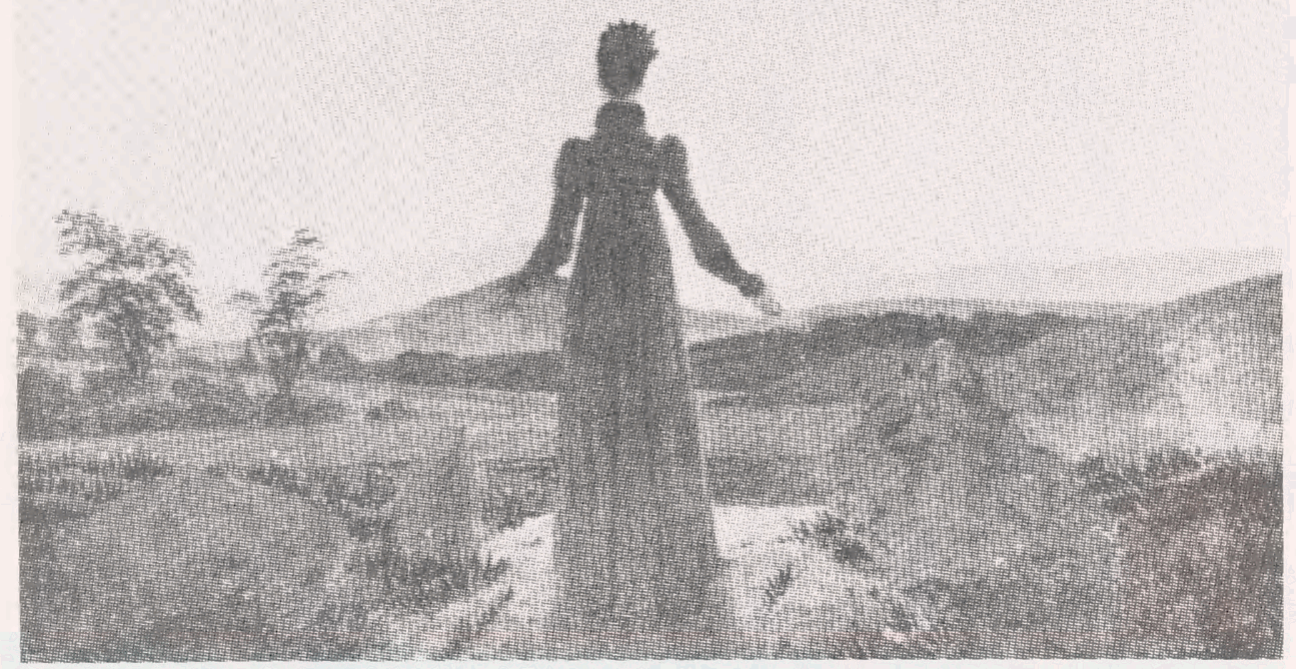

Caspar David Friedrich, Kvinde i aftensol/morgensol, ca. 1818. - Fra kaos og Kosmos.

udflydende begreb, bruges betegnelsen "realistisk musik" ikke, anfører Maegaard, der tager sit udgangspunkt i de resultater, de senere års musikhistoriske forskning har nået $\mathrm{i}$ retning af en mere præcis bestemmelse af det romantiske inden for musikken, idet man har betragtet dette ikke kun ud fra traditionelle stilistiske kriterier, men også fra en receptions- og produktionshistorisk synsvinkel. Fra en sådan undersøger Maegaard i sin studie bl.a. betydningen af to måder at forholde sig til musik på i det 19. århundrede - den ene knyttet til italiensk-fransk, den anden til tysk- $\varnothing$ strigsk musik. En Rossini-linje over for en Beethoven-linje. I opfattelsen af musikværket indebærer disse to linjer et skifte fra ornament til autonomt idékunstværk. Musikkens intention, der hidtil virkeliggjordes i opførelsen, er nu (med Beethoven) nedlagt i den musikalske tekst. Værket "har sin beståen hinsides de enkelte opførelser" (s. 104).

Med Per Øhrgaards analyse af Joseph von Eichendorffs roman Ahnung und Gegenwart fremdrages væsentlige sider af tysk romantik og af romantikken i almindelighed. Han lægger indledningsvis nogen afstand til det 19. århundredes romantikkritikeres (herunder Georg Brandes') opfattelse af den tyske romantik som hovedsagelig reaktion og fremhæver over for denne "forkortelse" af romantikken en række historiske og æstetiske forhold, der nu- 


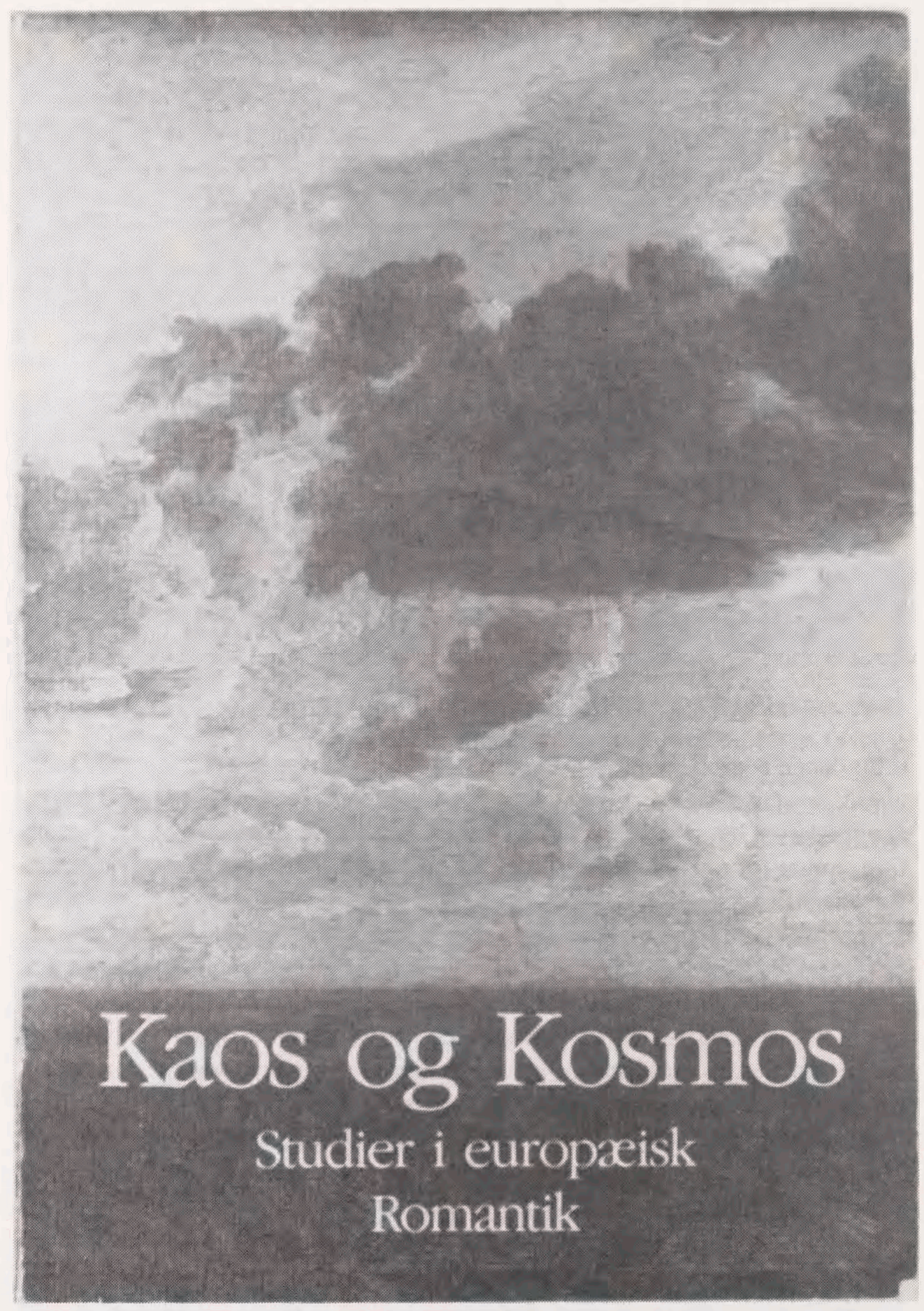

Bogens omslag: C.W. Eckersberg, Luftstudie over hav. 
ancerer billedet. En nuancering, der især er vigtig her, fordi Eichendorffs roman umiddelbart synes at bekræfte de vanlige forbehold over for tysk romantik. Øhrgaards fortolkning afdækker imidlertid, at dette værk med det romantiske yndlingsbegreb "anelse" som ledemotivet rummer en dobbeltholdning og en slags "romantikkens dementi af sig selv" (s. 178). To former for livsvalg og handling - "at gå i kloster eller drage ud i verden" (artiklens undertitel) - sættes over for hinanden, og det er ikke den egentlige hovedpersons valg, men den anden, mere "skjulte" hovedpersons eller helts holdning og valg, der er det bærekraftige og udtryk for en ny tid.

Efter de litteratur- og musikhistoriske behandlinger følger de to førnæunte kunsthistoriske: Hannemarie Ragn Jensens Det romantiske kvindeportrat og Marianne Marcussens Farve og følelse i romantikkens malerkunst. Med disse to artikler kommer man vidt omkring i dansk og europæisk billedkunst i første halvdel af det 19. århundrede. Under Ragn Jensens indkredsning af portrætmaleriet i Danmark klarlægger hun de danske maleres egenart i forhold til tyske og franske malerskoler og understreger, at det er vanskeligt at placere romantikken som begreb i dansk malerkunst, fordi nyklassicistiske, romantiske og naturalistiske strømme parallelt præger perioden.

En vigtig indgang til en tids billedkunst er dens opfattelse af farverne og deres system. Marianne Marcussens behandling af den tyske romantiske landskabs- og portrætmaler Philipp Otto Runges farvelære Die Farbenkugel (fra 1810) tilvejebringer et værdifuldt indblik i nogle teorier af central betydning for kunsten, håndværksmæssigt som æstetisk. Hvilende på den romantiske idé om sammenhængen mellem de eksakte videnskaber og kunst munder Runges teorier om farvernes fysiske relationer og orden ud i en erkendelse af denne naturlige orden som en guddommelig orden, der ikke blot kan forstås rationelt, men også sanses og opleves. Ja, den æstetiske sansning er for Runge "en konsekvens af den fysiske - guddommelige - orden" (s. 216).

Med sine spekulationer over en sammenhæng mellem den fysiske (naturens) orden og skønhedsværdierne har Runge spillet en stor rolle i æstetikken senere i det 19 . århundrede og helt frem til nyere tid.

I det tidl. nævnte sidste kapitel (uden forfatternavn) om malerkunsten fremdrages en række af det romantiske maleris karakteristiske navne og temaer. Figurmaleriet (med litterære og historiske emner), landskabsmaleriet og portrættet er de tre hovedformer, der med vekslende styrke gør sig gældende $\mathrm{i}$ de forskellige lande. Ikke mindst bliver portrættet, med den romantiske interesse for individet og det intime, sjælelige udtryk, en meget benyttet genre, skønt ikke særlig højt vurderet af kunstnerne selv. Vi fik herhjemme den blomstrende portrætkunst, som Ragn Jensen udførligt behandlede i sin 
artikel med bl.a. de store Johanne Luise Heiberg-portrætter som eksempler, og begge steder rejses spørgsmålet, om tidens danske malere egentlig kan kaldes romantikere. På deres udenlandsrejser så de, hvad der rørte sig i Europa, men som det på sin måde er tilfældet med de danske digteres tilegnelse af især den tyske romantiks ideer, "fulgte de siden deres egen overbevisning, mere eller mindre påvirket af samtidens strømninger" (s. 254).

Hans Boll-Johansens unders $\emptyset$ gelse af "relationerne mellem individ og stat i det 18. og 19. århundrede", under hovedoverskriften Romantik og nationalisme, står som en god, afsluttende beskrivelse og vurdering af romantikkens åndshistoriske og politiske indhold og dettes konsekvenser. Romantikkens dyrkelse af det nationale og folkesjælen, dens respekt for det enkelte individ og dens helhedstænkning er bestemmende for dannelsen af de forestillinger om folk og nation, individ og stat, frihed og solidaritet, som - under indflydelse af revolutionsideerne, den rousseauske "samfundspagt" og Hegels statsteori - tog form i perioden. På godt og ondt skulle de præge den efterfølgende tids politiske tænkning. Ligesom "nationalismen har Janus-ansigt", skal i denne forbindelse romantikkens dæmoniske sider ikke glemmes -"den uerkendte, dunkle natside, som først det 20. århundrede har vedkendt sig som en del af vores mentale fællesarv" (s. 247).

Det er vigtigt at besinde sig på romantikken i al dens kompleksitet, så vist som det 20. århundredes vel vægtigste arv fra det nittende er romantikken. Ikke mindst her $\mathrm{i}$ vort århundredes sidste årti kan behovet for at undersøge og forstå det, vi er efterkommere af og endnu må føle os beslægtet med, synes mere påtrængende end nogensinde. "Kaos og Kosmos" er en righoldig samling, der vil fremme forståelsen og fortsatte studier i epoken. De sagkyndige bidragydere har spændende indfaldsvinkler og er på flere punkter nytænkende; deres fremstilling er oftest klar og stimulerende. Det velvalgte billedmateriale (med fyldige undertekster, der i sig selv er et studium værd) har en samlende og inspirerende virkning. Som billede på det store univers, man udforsker i bogen, kunne næppe noget andet passe bedre end Eckersbergs fine "Luftstudie over hav", der er gengivet på dens omslag. 